\title{
Prevalence of chronic kidney disease in diabetic adult out-patients in Tanzania
}

\author{
Bonaventura C. T. Mpondo ${ }^{1 *}$, Eric Neilson ${ }^{2}$ and Alex Ernest ${ }^{3}$
}

\begin{abstract}
Despite the increasing number of patients with Diabetes Mellitus in sub-Saharan Africa, the magnitude of chronic kidney disease among diabetics has not been well established. A study done by Janmohamed et al. found chronic kidney disease in $83.7 \%$ of diabetics which is relatively higher than the prevalence reported elsewhere. However this study was conducted in schistosoma endemic area along the shores of Lake Victoria. Schistosomiasis has been reported to cause a range of renal diseases. Interpretation of these findings should therefore take into account the possibility of schistosomiasis as a possible confounder.
\end{abstract}

Keywords: Diabetes mellitus, Schistosomiasis, Microalbuminuria, Proteinuria, Chronic kidney disease

\section{Correspondence}

We have read the article by Janmohamed et al. [1] published in your journal with much pleasure and interest. The authors enrolled 369 adult diabetic out-patients and screened them for renal dysfunction by measuring proteinuria, microalbuminuria and serum creatinine. In this study, the authors found that $83.7 \%$ of the study participants had chronic kidney disease (CKD) defined as an estimated glomerular filtration rate (eGFR) $\leq 60 \mathrm{ml} /$ $\mathrm{min} / 1.73 \mathrm{~m}^{2}$ or having evidence of kidney damage (microalbuminuria or overt proteinuria). The prevalence of albuminuria was found to be $80.0 \%$ in this cohort. Out of the patients with albuminuria, $45.8 \%$ had microalbuminuria alone and $34.1 \%$ of the participants had overt proteinuria. This study was conducted in a tertiary level hospital located in Mwanza, Tanzania, in the Lake Victoria zone.

The rates of overt proteinuria found in this study were higher than those observed in other similar studies in sub-Saharan Africa [2-4]. Another study done in a different tertiary hospital in Dar es Salaam Tanzania found the overall prevalence of microalbuminuria to be $10.7 \%$ and macroalbuminuria to be $4.9 \%$. In this study, patients with type 1 diabetes were found to have microalbuminuria at a rate of $12 \%$ and macroalbuminuria at a rate of $1 \%$. Patients with type 2 diabetes were found to

\footnotetext{
*Correspondence: boniempondo@gmail.com

'Department of Internal Medicine, School of Medicine and Dentistry, College of Health and Allied Sciences, The University of Dodoma, Dodoma, Tanzania Full list of author information is available at the end of the article
}

have microalbuminuria at $9.8 \%$ and macroalbuminuria at $7.2 \%$ [5]. The rates are significantly lower when compared to the study by Janmohamed et al.

The study by Janmohamed et al. was conducted in Mwanza, Tanzania, located along the shores of Lake Victoria. Previous studies have demonstrated a high prevalence of Schistosomiasis infection in this region [6-8]. The role of Schistosomiasis in causing renal disease has been well established. Existing reports show that Schistosomiasis is associated with a range of renal diseases from cystitis to immune mediated glomerulopathy [9-12].

Other studies assessing renal dysfunction in this region have shown relatively higher rates of renal dysfunction compared to studies elsewhere [13]. This study investigating HIV-infected patients initiating ART also did not screen for Schistosomiasis. In children, a study assessing the prevalence of renal dysfunction among HIV-infected and uninfected patients found that Schistosomiasis was a strong predictor of renal insufficiency in both HIVinfected and HIV-uninfected individuals [14]. These findings demonstrate that, in Schistosomiasis endemic areas, the high prevalence of renal insufficiency can be, at least partially, due to the parasitic infection.

The authors failed to mention the possible contribution of Schistosomiasis as a likely confounder in the observed high prevalence of renal insufficiency. In interpreting these results, it is important to take into consideration the high prevalence of this disease in the study setting and its possible role in causing renal diseases. The failure to screen 
for Schistosomiasis should have been mentioned as a one of the limitations of their study.

\section{Abbreviations}

ART, antiretroviral therapy; CKD, chronic kidney disease; eGFR,

estimated glomerular filtration rate; HIV, human immunodeficiency virus

\section{Acknowledgments}

We would like to recognize the support provided by staff members, college of Health sciences of The University of Dodoma, department of Internal Medicine in particular.

\section{Availability of data and materials}

The information supporting the conclusions of this article are reported within the article.

\section{Authors' contributions}

$B C M, E N$ and $A E$ did the literature search, wrote the manuscript.

All authors have read and approved the final manuscript.

\section{Competing interests}

The authors declare that they have no competing interests.

\section{Consent for publication}

Not applicable.

\section{Ethics approval and consent to participate}

Not applicable.

\section{Author details}

'Department of Internal Medicine, School of Medicine and Dentistry, College of Health and Allied Sciences, The University of Dodoma, Dodoma, Tanzania. ${ }^{2}$ Peace Corps/SEED Global Health Service Partnership, Massachusetts General Hospital Center for Global Health, Boston, MA, USA. ${ }^{3}$ Department of Surgery and Maternal Health, School of Medicine and Dentistry, College of Health and Allied Sciences, The University of Dodoma, Dodoma, Tanzania.

Received: 9 October 2015 Accepted: 16 June 2016

Published online: 08 July 2016

\section{References}

1. Janmohamed MN, Kalluvya SE, Mueller A, Kabangila R, Smart LR, Downs JA, et al. Prevalence of chronic kidney disease in diabetic adult out-patients in Tanzania. BMC Nephrol. 2013;14:183. Available from: http://www.pubmedcentral.nih.gov/articlerender. fcgi?artid=3765892\&tool=pmcentrez\&rendertype=abstract.

2. Rahlenbeck SI, Gebre-Yohannes A. Prevalence and epidemiology of micro- and macroalbuminuria in Ethiopian diabetic patients. J Diabetes Complications. 1997;11:343-9. Available from: http://www.ncbi.nlm.nih. gov/pubmed/9365876

3. Rasmussen JB, Thomsen JA, Rossing P, Parkinson S, Christensen DL, Bygbjerg IC. Diabetes mellitus, hypertension and albuminuria in rural Zambia: a hospital-based survey. Trop Med Int Health. 2013;18:1080-4. Available from: http://www.ncbi.nlm.nih.gov/pubmed/23763632

4. Mafundikwa A, Ndhlovu CE, Gomo Z. The prevalence of diabetic nephropathy in adult patients with insulin dependent diabetes mellitus attending Parirenyatwa Diabetic Clinic, Harare. Cent Afr J Med. 2007;53:1-6. Available from: http://www.ncbi.nlm.nih.gov/pubmed/20353128.

5. Lutale JJK, Thordarson H, Abbas ZG, Vetvik K. Microalbuminuria among Type 1 and Type 2 diabetic patients of African origin in Dar Es Salaam, Tanzania. BMC Nephrol. 2007;8:2. Available from: http://www.pubmedcentral.nih.gov/ articlerender.fcgi?artid=1781433\&tool=pmcentrez\&rendertype=abstract.

6. Mazigo HD, Nuwaha F, Kinung'hi SM, Morona D, Pinot de Moira A, Wilson S, et al. Epidemiology and control of human schistosomiasis in Tanzania. Parasit Vectors. 2012;5:274. Available from: http://www.pubmedcentral.nih. gov/articlerender.fcgi?artid=3549774\&tool=pmcentrez\&rendertype=abstract.
7. Barda B, lanniello D, Zepheryne H, Rinaldi L, Cringoli G, Burioni R, et al. Parasitic infections on the shore of Lake Victoria (East Africa) detected by Mini-FLOTAC and standard techniques. Acta Trop. 2014;137:140-6. Available from: http://www.ncbi.nlm.nih.gov/pubmed/24865791.

8. Chofle AA, Jaka H, Koy M, Smart LR, Kabangila R, Ewings FM, et al. Oesophageal varices, schistosomiasis, and mortality among patients admitted with haematemesis in Mwanza, Tanzania: a prospective cohort study. BMC Infect Dis. 2014;14:303. Available from: http://www. pubmedcentral.nih.gov/articlerender. fcgi?artid=4065539\&tool=pmcentrez\&rendertype=abstract.

9. Sobh MA, Moustafa FE, Ramzy RM, Deelder AM, Ghoneim MA. Schistosoma haematobium-induced glomerular disease: an experimental study in the golden hamster. Nephron. 1991;57:216-24. Available from: http://www.ncbi. nlm.nih.gov/pubmed/1902286

10. Sobh M, Moustafa F, Ramzy R, Saad M, Deelder A, Ghoneim M. Schistosoma mansoni nephropathy in Syrian golden hamsters: effect of dose and duration of infection. Nephron. 1991;59:121-30. Available from: http://www.ncbi.nlm.nih.gov/pubmed/1944725.

11. dos-Santos WLC, Sweet GMM, Bahiense-Oliveira M, Rocha PN. Schistosomal glomerulopathy and changes in the distribution of histological patterns of glomerular diseases in Bahia, Brazil. Mem Inst Oswaldo Cruz. 2011;106:901-4 Available from: http://www.ncbi.nlm.nih.gov/pubmed/22124564.

12. Duarte DB, Vanderlei LA, de Azevêdo Bispo RK, Pinheiro ME, da Silva GB, Martins AM, et al. Renal function in hepatosplenic schistosomiasis-an assessment of renal tubular disorders. PLoS One. 2014;9:e115197. Available from: http://www.pubmedcentral.nih.gov/articlerender. fcgi?artid=4274079\&tool=pmcentrez\&rendertype=abstract.

13. Msango L, Downs JA, Kalluvya SE, Kidenya BR, Kabangila R, Johnson WD, et al. Renal dysfunction among HIV-infected patients starting antiretroviral therapy. AIDS. 2011;25:1421-5. Available from: http://www.pubmedcentral.nih.gov/ articlerender.fcgi?artid=3631352\&tool=pmcentrez\&rendertype=abstract.

14. Kayange NM, Smart LR, Downs JA, Maskini M, Fitzgerald DW, Peck RN. The influence of HIV and schistosomiasis on renal function: a cross-sectional study among children at a hospital in Tanzania. PLoS Negl Trop Dis. 2015;9: e0003472. Available from: http://www.pubmedcentral.nih.gov/articlerender. fcgi?artid=4303314\&tool=pmcentrez\&rendertype=abstract.

Submit your next manuscript to BioMed Central and we will help you at every step:

- We accept pre-submission inquiries

- Our selector tool helps you to find the most relevant journal

- We provide round the clock customer support

- Convenient online submission

- Thorough peer review

- Inclusion in PubMed and all major indexing services

- Maximum visibility for your research

Submit your manuscript at www.biomedcentral.com/submit 